\title{
Book Review: Making all the Difference. Psychotherapy: The Art of Wooing Nature
}

\author{
Nora M. Kramer, MD \\ Jefferson Medical College, Philadelphia PA
}

Follow this and additional works at: https://jdc.jefferson.edu/jeffjpsychiatry

Part of the Psychiatry Commons

Let us know how access to this document benefits you

\section{Recommended Citation}

Kramer, MD, Nora M. (1989) "Book Review: Making all the Difference. Psychotherapy: The Art of Wooing Nature," Jefferson Journal of Psychiatry. Vol. 7 : Iss. 1 , Article 13.

DOI: https://doi.org/10.29046/JJP.007.1.012

Available at: https://jdc.jefferson.edu/jeffjpsychiatry/vol7/iss1/13

This Article is brought to you for free and open access by the Jefferson Digital Commons. The Jefferson Digital Commons is a service of Thomas Jefferson University's Center for Teaching and Learning (CTL). The Commons is a showcase for Jefferson books and journals, peer-reviewed scholarly publications, unique historical collections from the University archives, and teaching tools. The Jefferson Digital Commons allows researchers and interested readers anywhere in the world to learn about and keep up to date with Jefferson scholarship. This article has been accepted for inclusion in Jefferson Journal of Psychiatry by an authorized administrator of the Jefferson Digital Commons. For more information, please contact: JeffersonDigitalCommons@jefferson.edu. 


\title{
Making All The Difference
}

\author{
PSYCHOTHERAPY: THE ART OF WOOING NATURE \\ Sheldon Roth, M.D. \\ Jason Aronson Inc. \\ Northvale, N.J. (1987) \\ 294 pages
}

\section{Nora M. Kramer, M.D.}

Here let us pause for a moment to assure the analyst that he has our sincere sympathy in the very exacting demands he has to fulfill in carrying out his activities. It almost looks as if analysis were the third of those "impossible professions" in which one can be sure beforehand of achieving unsatisfying results. (1)

Freud could well have been directing his sympathy to first year residents in psychiatry whose "exacting demands" are exacerbated by anxious attempts to develop a persona both comfortable for the individual resident and proper for the new position. As first year residents, we frequently experience the uncertainty of choosing from the many paths available to psychotherapists-in-training. Yet the ultimate objective remains the same for each of us: to develop our individual persona so that we may serve our patients while remaining true to ourselves. Often relying on little more than instinct, we meander along unmarked roads, groping for this ultimate goal. Still, as Freud queried: ". . . where and how is the poor wretch to acquire the ideal qualifications which he will need in his profession." (2) Where and how indeed?

Sheldon Roth's Psychotherapy: the Art of Wooing Nature provides useful and welcome roadmaps to assist us on the journey. In seventeen succinct chapters, Dr. Roth has penned a veritable "handbook" to young residents. His discussions range from such weighty topics as transference, silence and dreams to those less sublime, such as conducting the initial interview and strategically placing the tissues and office clock. Unfortunately, his illustrations are often too "classical," depicting situations too unusual to assist those laboring in the wards and crisis centers of urban hospitals. The depth and quality of information is, moreover, inconsistent. The chapters do not flow smoothly, often lacking transitions. Yet despite these weaknesses, which are essentially structural, The Art of Wooing Nature offers a great deal of down-to-earth information invaluable to fledgling psychotherapists. Particularly useful is a very extensive bibliography, divided by subject, at the end of the book.

From the outset, the author confronts us with a paradox inherent in the practice of psychotherapy. He notes, in a chapter entitled "The Personality of the Psychotherapist: Why Practice an Impossible Profession?” that while the profession attracts those wishing to engage fully in interpersonal relationships, 
the actual practice often leads to isolation and loneliness. The doctor-patient relationship, based on confidentiality, dictates that conversations around which our work-life revolves must not proceed beyond the office door. For the beginning psychotherapist, this is especially difficult to put into practice. Yet despite this frustration, Dr. Roth assures professional gratification. He quotes from Jung's autobiography:

From my encounters with patients I have learned an enormous amount, not just knowledge, but above all insight into my own nature... The finest and most significant conversations of my life were anonymous. (3)

Dr. Roth stresses the necessity of a therapist's own therapy. To help patients come to understand and forgive themselves, the therapist must first understand and forgive herself. She must be unencumbered by personal guilt or shame which, as Roth describes, may intensify countertransference. Selfappreciation and self-awareness, both enhanced by therapy, are indispensable for maintaining the objectivity and neutrality demanded of a therapist.

Dr. Roth's excellent chapter on transference provides a solid foundation for understanding this essential concept. He describes the unconcious source of transference which must be tapped and clarified for successful treatment. With clear clinical examples, he calls our attention to the need for therapeutic neutrality in order to achieve objectivity of perception and judgment.

For instance, he describes a young man who arrives for his session under the influence of marijuana. The patient evidently wishes to be reproached for his behavior. However, it is soon revealed that he is merely repeating delinquent childhood conduct which was designed to prod his distant and distracted mother into acting as a responsible parent. Dr. Roth also refers to "transference acting-out" of the borderline patient. Overly demanding, often idealizing the therapist and trying to gain the nurturing environment lost or never had, the borderline's acting-out of the past represents a major challenge to the neutral therapeutic relationship.

Roth's chapter on countertransference also contains basic definitions and numerous examples. My favorite illustration is a humorous, if fanciful, tale by Rabbi Nachman of Bratzlav, who antedated by over 100 years Freud's labeling of the concept. Rabbi Nachman relates the homily of a young prince who went crazy and convinced himself that he was a turkey. He sat naked under a table and ate only oats. A wise man, seeking to cure the prince, strips naked, begins to eat only oats and joins him under the table. Gradually, the wise man dresses and begins to eat normally, gently coaxing the young man to join him at each stage until, finally, the prince is cured. As Dr. Roth writes: the wise man "works slowly, with little confrontation, takes the empathic position, and allows the prince to move from a neutral observing position to a slow symbiosis and fusion, whereby he and the prince both experience themselves as turkeys. Only when this turkey-transference symbiosis has been achieved does the sage behave in 
ways that are basically action-interpretations aimed at separation and individuation" (4). We should remember that Freud did not work in an historical vacuum.

Dr. Roth's chapter on dreams is his best. He provides concrete, practical pointers, such as the importance of the therapist's silence after the patient relates the dream, and discusses theoretical support of universal symbols. He describes dreams as representing the unveiling of the unconscious and the role they play in treatment. He concludes:

Dreams are very special. . . . Through dreams the most nonliterary, unpoetic people produce mythic narratives, which are often so basic to human nature that they transcend the individual's concerns and reveal universal truths. (5)

Perhaps this last quote best captures the essence of The Art of Wooing Nature, a kind and gentle reminder that within each patient is an individual whose beauty is waiting to be drawn out-wooed-by the therapist. Much like a valuable piece of rock that has been battered by wind and rain, the patient's inner nature is ready to be shaped by the therapist's art into a golden creation able to stand alone, and whole, against the elements.

\section{REFERENCES}

1. Roth S: (1987). Psychotherapy: The Art of Wooing Nature. Northvale, N.J.: Jason Aronson Inc., p 7

2. Id., $\mathrm{p} 7$

3. Id., p 16

4. Id., p 43

5. Id., p 183 